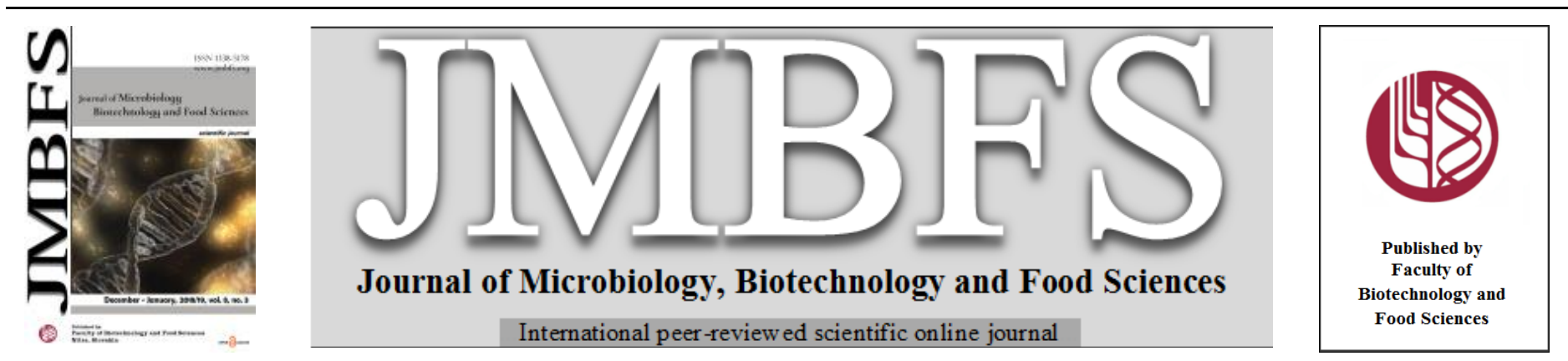

\title{
POSSIBILITIES OF LECTIN HELIX POMATIA AGGLUTININ (HPA) USE IN RABBITS INSEMINATION
}

\author{
Martin Fik* \\ Address(es): Ing. Martin Fik, PhD.,
}

Slovak university of Agriculture, Faculty of Agrobiology and Food Resources, Department of Poultry and Small Livestock, Tr. A. Hlinku 2, 94976 Nitra, Slovakia.

*Corresponding author: martin.fik@gmail.com

doi: $10.15414 / j m b f s .2018-19.8 .3 .951-954$

ARTICLE INFO

Received 17. 5. 2018

Revised 25. 9. 2018

Accepted 11. 10. 2018

Published 1. 12. 2018

Regular article

open $\odot$ access

\begin{abstract}
The aim of this work was to analyse the effect of incubation HPA (lectin Helix pomatia agglutinin) with ID (insemination dose) on reproduction parameters (conception ratio, number of live and dead born of pups and birth weight of pups) of rabbits. The experiments were carried out under conditions of 2 rabbit breeds (production breed $\mathrm{P}$ and experimental breed E). Fresh ID, in sperm concentrations 25 mil. / $0.5 \mathrm{ml}$ ID, were divided into control ID (without HPA) and experimental ID (with HPA). HPA was added to the experimental ID in concentrations $1 \mu \mathrm{g}$ HPA / 1x10 $0^{6}$ spermatozoa (30 - 60 minutes of incubation before AI - artificial insemination). Conception ratios obtained from 2 different breeds $(\mathrm{P}, \mathrm{E})$ showed minor improvement $(+2.67 \% \mathrm{P} ;+7.36 \% \mathrm{E})$ between the monitored groups of females, however without statistically significant differences $\left(\mathrm{P} \chi^{2}=0.03 ; \mathrm{E} \chi^{2}=0.11\right)$. Number of live born pups in litter obtained from breeds $\mathrm{P}$ and $\mathrm{E}$ showed minor improvement $(+0.37 \mathrm{pcs} \mathrm{P}(\mathrm{p}>0.05) ;+0.95$ pcs $\mathrm{E}(\mathrm{p} \leq 0.05))$ compared to the control groups. The weight of live pups among the monitored groups was comparable. It can be concluded from the present study that incubation of ID with lectin HPA had been positively affected by the observed reproductive parameters. The statistically significant difference was found only in the number of live-born pups in the litter. The price of lectin is too high for breeding in common breeding practice.
\end{abstract}

\section{INTRODUCTION}

Extenders are characterized as substances added to the insemination dose in order to preserve its fertilization ability and extension of spermatozoa viability. Anchordogery et al. (1987) reported that some additives added to the semen have the ability to protect its individual components and affect spermatozoa stability. The positive effect of implementers on livestock insemination is described by various authors: IGF - I. Insulin growth factor- Vickers et al (1999) (rats); Champion et al. (1997) (equine spermatozoa); caffeine - Tathan et al. (2003) (buffalo and cattle); Matejašáková et al. (2005) (sheep); Riha et al. (2006) (sheep), Slanina et al. (2018) (turkey); heparin and hyaluronan Januskauskas et al. (2000) (cattle); Heparin - Lapointe et al. (1996) (cattle), Parrish et al. (1993) (cattle); Fik et al. (2008a,b,c) (rabbit); Fik (2009) (rabbit) Vašíček (2009) (rabbit); Fik and Malíková (2013) (rabbit); Fik et al. (2014) (rabbit); buserelin acetate (rabbit) Vicente et al. (2011); tilmicosin - Slanina et al. (2016) (rabbit); lecirelinum - Fik (2018) (rabbit). A variety of substances isolated from natural sources may exhibit protective or antioxidant properties on the spermatozoa thus extending the lifespan of stored ejaculates. Chlamydomonas has been shown to possess antimicrobial, anti-inflammatory and antioxidant properties, turning the extract into a potential candidate for preserving liquid animal semen during in vitro storage (Tvrdá et al. 2016). Tirpák et al. (2017) monitored to determinate the effect of various taurine concentrations on rabbit spermatozoa in in vitro conditions with the potential use in routine artificial insemination. This study shows improved viability and motility in in vitro conditions. The synthetic antioxidants are one of the solutions; however, the naturally occurring substances are preferable due its chemical diversity, structural complexity, availability, intrinsic biologic activity or lack of substantial toxic effects (Tvrdá et al., 2015a). Saha et al. (2014) showed antibacterial and antioxidant activities of a food lectin isolated from the seeds of lablab purpureous. Zibrín et al. (1995) indicates that the tunics of seminal antioxidants that protect sperm against oxidative damage induced by reactive oxygen species (ROS) are weakened by diluting semen in the preparation of insemination doses. Damage to the cytoplasmic membrane and acrosomal to form vesicles, or by changing its permeability causes the release and outflow of acrosomal enzymes and thereby the reducing of fertilization ability. Tvrdá $\boldsymbol{e t}$ al. (2015b) reported antioxidant efficiency of resveratrol on oxidative stress-induced damage in bovine spermatozoa. Hashim et al. (2017) showed, that natural antioxidant such as vitamin $\mathrm{C}$ and vitamin $\mathrm{E}$ were used to protect and improve the post-thaw quality of bovine insemination doses. The appropriateness of adding of antioxidants (a-tocopherol acetate, glutathione peroxidase, Aromex ${ }^{\circledR}$, resveratrol, resveratrol + vitamin $\mathrm{E}$, resveratrol + Aromex ${ }^{\circledR}$, resveratrol $\left.+\mathrm{GP}\right)$ into the semen of rams is also indicate Sarlós et al. (2002), who found that after their addition to demonstrably improve sperm motility and decreased the frequency of acrosome defects. Fik and Malíková (2013) showed positive effect of heparin on selected quality indicators of ID of rabbits. Fik et al. (2011) reported that after the addition of $\mathrm{GnRH}$ to the insemination dose of rabbits has increased of nonphysiological - circular movements of the spermatozoa and spermatozoa agglutination (at both monitored concentrations of GnRH). HPA lectin is currently used in human experimental medicine (cancer research). These studies indicate that HPA is best suited to recognise a glycotope on adenocarcinomas Mitchell and Schumacher (1999). Many studies have used lectinscarbohydrate-binding proteins of non-immune origin to identify changes in glycosylation in cancer cells and tissues (Baldus and Hanisch 2000; Takano et al. 2000; Handerson et al. 2005; Blonski et al. 2007). Lectins are oligomeric proteins with saccharide-binding sites that can recognize and bind particular glycoconjugates. Among others, the lectin from the Roman snail Helix pomatia has emerged as a promising lectin in this regard (Brooks 2000). The lectin Helix pomatia agglutinin (HPA), which is isolated from the edible snail Helix pomatia, selectively binds to $\alpha-\mathrm{N}$-acetyl-galactosamine residues and type A erythrocytes This lectin exists as a hexamer with a molecular weight of approximately 70,000 daltons. Fluorescent lectins are versatile probes with diverse applications, including detection of cell surface and intracellular glycoconjugates by microscopy and flow cytometry, localization of glycoproteins in gels, precipitation of glycoproteins in solution, and agglutination of specific cell types. HPA is a N-acetylgalactosamine (GalNAc) binding lectin found in the albumen gland of the roman snail. As a constituent of perivitelline fluid, HPA protects fertilized eggs from bacteria and is part of the innate immunity system of the snail. The peptide sequence deduced from gene cloning demonstrates that HPA belongs to a family of carbohydrate-binding proteins recently identified in several invertebrates. This domain is also present in discoidin from the slime mold Dictyostelium discoideum (Sanchez et al. 2006). Hermo et al. (1992) showed quantitative changes of Ricinus communis agglutinin I and Helix pomatia lectin binding sites in the acrosome of rat spermatozoa during epididymal transit. In the field of livestock reproduction is effects of lectins are only minimally described. 
Rabbits are an ideal model for studying the effects of lectins on reproductive properties.

The aim of this work was to analyse the impact of implementer - lectin HPA in insemination dose in rabbits on selected reproductive parameters.

\section{MATERIAL AND METHODS}

HPA analysis of reproductive performance was focused on reproductive parameters: conception ratio, number of live and dead born of pups and birth weight of pups. The experiments was realized on two different places out under conditions of 2 rabbit breeds (experimental breed and production breed). Semen was collected using an artificial vagina (at $50^{\circ} \mathrm{C}$ ). Production breed (P): Breeding focused on the production of broilers (Močenok district Nitra). Does (1800 pieces) broiler strain Hycole (commercial hybrid). Does were inseminated on the 19th day post partum. 238 females (100 experimental group - experimental 1; 138 control group - control 1) were used for monitoring. Fresh ID (125 ml) (strain Hycole; 13 males) were used Experimental breed (E): Experimental farm of the Animal Production Research Centre Nitra (Slovak Republic), does (250 pieces) synthetic broiler line M 91, fresh ID (insemination dose) from male synthetic broiler line P 91. Does were inseminated on the 11th day post partum. 91 females (54 experimental group experimental 2; 37 control group - control 2) were used for monitoring. Fresh ID $(50 \mathrm{ml}) \quad$ (meat line P19; 10 males) were used. In all monitored breeds (farms) were female (primiparous and multiparous up to 7 litters) hormonal treatment before AI (48 hours. Sergon - PMSG). Fresh ID (used commercial diluent from the company Minitübe), in sperm concetrations $40-50$ mil. / $0.5 \mathrm{ml}$ ID. Immediately after AI were (all does, control and experimental does) administered intramuscularly $\mathrm{GnRH} 0.1 \mathrm{ml}=2.5$ $\mu \mathrm{g} / 1$ doe.

\begin{tabular}{|c|c|c|c|c|}
\hline \multirow[t]{2}{*}{ Studied indicators } & Group & $\begin{array}{l}\text { Insemination } \\
\text { dose (ID) }\end{array}$ & $\begin{array}{l}\text { Implementer in } \\
\text { ID }\end{array}$ & $\begin{array}{l}\text { Incubation } \\
\text { before AI }\end{array}$ \\
\hline & & $\begin{array}{l}\text { Sperm } \\
\text { concentrations } \\
\text { mil. / } 0.5 \mathrm{ml} \text { ID }\end{array}$ & HPA & \\
\hline \multirow[t]{2}{*}{$\begin{array}{l}\text { Production breed } \\
P\end{array}$} & Experimental 1 & $40-50$ & $\begin{array}{l}\text { concetrations } 1 \mu \mathrm{g} \\
\text { HPA / } 1 \times 10^{6} \\
\text { spermatozoa }\end{array}$ & $30-60 \mathrm{~min}$ \\
\hline & Control 1 & $40-50$ & Without HPA & $30-60 \mathrm{~min}$ \\
\hline \multirow[t]{2}{*}{$\begin{array}{l}\text { Experimental breed } \\
E\end{array}$} & Experimental 2 & $40-50$ & $\begin{array}{l}\text { concetrations } 1 \mu \mathrm{g} \\
\text { HPA / } 1 \times 10^{6} \\
\text { spermatozoa }\end{array}$ & $30-60 \mathrm{~min}$ \\
\hline & Control 2 & $40-50$ & Without HPA & $30-60 \mathrm{~min}$ \\
\hline
\end{tabular}

Monitored parameters:

conception ratio (in \%, post partum)

number of live-born pups

number of dead-born pups

weight of pups (in g, immediately after birth)

The results of the conception ratios (relative values) were compared using chi quadrate $\left(\chi^{2}\right)$. The significance of differences between the compared groups was determined according to the t-test. The Microsoft Excel statistical program was used.

\section{RESULTS AND DISCUSSION}

Conception ratios obtained from 2 different breeds (P, E) showed minor improvement $(+2.67 \% \mathrm{P} ;+7.36 \% \mathrm{E})$ between the monitored groups of females, however without statistically significant differences $\left(\mathrm{P} \chi^{2}=0,08^{(-)} ; \mathrm{E} \chi^{2}\right.$ $\left.=0,75^{(-)}\right)$. Positive effect $(\mathrm{p} \leq 0.05)$ of HPA lectin incubation on number of liveborn pups $(+0.95 \mathrm{pcs})$ was detected in the breed E. Breed $\mathrm{P}$ also showed improvement in number of live-born pups (+ $0.37 \mathrm{pcs})$ in experimental group, however without statistically significant differences. In weight of live-born pups was detected minimal differences. The results of analysis of selected reproduction parameters are presented in table 2 . Fik $\boldsymbol{e t} \boldsymbol{a l}$. (2014) in their study evaluated reproductive performance of does after treatment with insemination dose implementer heparin. Authors found improvement in the conception ratio after adding the implement ( 74.50 versus $81.80 \%$ ), but without statistically significant differences. Fik (2018) reported (rabbit) that the ID with extender GnRH with a concentration of $0.3 \mathrm{ml}$ of commercially available Supergestran to $0.5 \mathrm{ml}$ of ID completely replaces intramuscular administration, which is normally used in rabbit breeding at AI, but the number of live-born pups was not affected by $\mathrm{GnRH}$ extender. Experiments on nulliparous females, flushing out of zygotes, showed low improvement in the conception ratio in favor of the group of inseminated females with the treated ID $(77.66 \%)$ versus the group of females inseminated with control ID (74.55\%) (no statistically significant differences) Gogol (2016) reported the negative effect of goserelin and leuprolide added to the ID (in rabbit). The kindling rate was $80.5 \%$ in group G10 (10 $\mu \mathrm{g}$ of goserelin added to the ID) and $75.0 \%$ in group L10 (10 $\mu \mathrm{g}$ of leuprolide added to the ID). The kindling rates in Groups G5 (5 $\mu \mathrm{g}$ of goserelin added to the semen dose) and L5 (5 $\mu \mathrm{g}$ of leuprolide added to the semen dose) were significantly lower than in the control group $(60.0 \%, 54.2 \%$ and $85.9 \%$, respectively). The number of liveborn rabbits was not significantly affected by the ovulation induction. Ondruška et al. (2008) showed that intravaginal administration of GnRH (in dose 7.5 $\mu \mathrm{g} /$ doe) intravaginal, through ID positively induces ovulation of does $(+9,35 \%$ conceptul rate). Fik and Malíková (2013) reported that the rabbit spermatozoa incubation with heparin gave better reproduction results. The authors reported an improvement in the conception ratio (70.06 versus $55.94 \%)$, the number of liveborn pups / litter ( 8.69 versus $8.41 \mathrm{pcs})$, the number of live-born pups / inseminated female (6.28 versus $4.89 \mathrm{pcs})$, but without statistically significant differences. Parkányi et al. (2005) reported that intravaginal administration of the DMSO (the concentration of DMSO in ID $0.5 \mathrm{M}$ and $1.75 \mathrm{M}$ ) revealed a benefit in the conception ratio versus the control group. The authors reported a conception ratio in the experimental group with a statistically significant difference compared to the control group. The aim of study Slanina et al. (2016) was to examine the effects of tilmicosin on rabbit spermatozoa viability and motility parameters during short-term in vitro incubation at $37^{\circ} \mathrm{C}$. Concentration of tilmicosin 0.350 mg.ml-1 has a positive impact on motility $(72.39 \pm 15.62 \%$, $\mathrm{p}<0.001)$ and progressive motility $(54.28 \pm 21.23 \%, \mathrm{p}<0.01)$ of rabbi spermatozoa after 4 hours of incubation in vitro at $37^{\circ} \mathrm{C}$. Supplementation of tilmicosin led to preservation of the cell over all time periods of the in vitro incubation. The results indicate that tilmicosin could be used to semen extenders without negative effects on rabbit spermatozoa motility and viability. Ďuračka $\boldsymbol{e t}$ al. (2017) monitored in vitro effects of selected biologically active compounds (resveratrol-RES, quercetin-QUE, curcumin-CUR, epicatechin-EPI, isoquercitrin-ISO) on rabbit spermatozoa motility behaviour. The motility assessment revealed different behavior patterns, specific and unique to each of the studied biomolecules. After $8 \mathrm{~h}$ of in vitro culture, the highest sperm motility was detected in experimental groups subjected to $10 \mu \mathrm{mol} / \mathrm{L}$ RES $(\mathrm{P}<0.05) ; 1-10$ $\mu \mathrm{mol} / \mathrm{L}$ QUE $(\mathrm{P}<0.01$ with respect to $1 \mu \mathrm{mol} / \mathrm{L}$ QUE; $\mathrm{P}<0.001$ in case of 5 and $10 \mu \mathrm{mol} / \mathrm{L}$ QUE); $1 \mu \mathrm{mol} / \mathrm{L}$ CUR $(\mathrm{P}<0.01) ; 1-100 \mu \mathrm{mol} / \mathrm{L}$ EPI $(\mathrm{P}<0.01$ in relation to 50,10 and $5 \mu \mathrm{mol} / \mathrm{L}$ EPI; $\mathrm{P}<0.001$ with respect to 100 and $1 \mu \mathrm{mol} / \mathrm{L}$ EPI) and $10 \mu \mathrm{mol} / \mathrm{L}$ ISO $(\mathrm{P}<0.05)$ when compared to the untreated Control. Desantis et al. (2010) studied lectin-binding sites on ejaculated stallion spermatozoa during breeding and non-breeding periods. Stallion spermatozoa from semen collected in Southern Italy during the breeding (June-July) and nonbreeding (December-January) periods were analyzed by means of twelve lectins to evaluate the glycoconjugate pattern and to verify whether there are any seasonal differences in the glycosylation pattern of the sperm glycocalyx. The acrosomal cap showed reactivity for Maackia amurensis (MAL II), Sambucus nigra (SNA), Arachis hypogaea (PNA), Glycine max (SBA), Helix pomatia (HPA), Canavalia ensiformis (Con A) Triticum vulgaris (WGA), and Griffonia simplicifolia isolectin II (GSA II) in breeding and non-breeding ejaculated sperm. These results indicate that the surface of stallion sperm contains different glycocalyx domains and that the glycosylation pattern undergoes changes during the breeding and non-breeding periods. Cross and Overstreet (1987) studied changes in the binding of fluoresceinated lectins to human spermatozoa during in vitro capacitation. Spermatozoa was labeled with 100 micrograms/ml FITCconjugated lectin at $4^{\circ} \mathrm{C}$ for $30 \mathrm{~min}$. Authors simultaneously used Hoechst stain 33258 as a supravital stain to help differentiate surface from intracellular lectin labeling. From the 14 lectins studied, six (phytohemagglutinin-E, concanavalin A, Ricinus communis agglutinin-I, and the lectins of wheat germ, Lens culinaris, and Pisum sativum) were bound to the entire surface of spermatozoa, sometimes with minor local heterogeneity. Three lectins (from peanut, Maclura pomifera, and soybean) were usually bound in a punctate manner, with more label on the tail than on the head. Five lectins (Ulex europaeus, Dolichos biflorus, Helix pomatia, and Vicia villosa lectins, and lectin II of Griffonia simplicifolia) were bound very poorly but not at all to the spermatozoa surface. Yangyang $\boldsymbol{e t}$ al. (2016) showed, that lectin microarrays are a powerful tool for such investigations and have been successfully applied for a variety of glycobiological studies. However, most of the current lectin microarrays are primarily constructed from 
plant lectins, which are not well suited for studies of human glycosylation because of the extreme complexity of human glycans. Authors constructed a human lectin microarray with 60 human lectin and lectin-like proteins. All of the lectins and lectin-like proteins were purified from yeast, and the most showed binding to human glycans. To demonstrate the applicability of the human lectin microarray, human spermatozoa were probed on the microarray and strong bindings were observed for several lectins, including galectin-1, 7, 8, GalNAc-
T6, and ERGIC-53 (LMAN1). These bindings were validated by flow cytometry and fluorescence immunostaining. The other mass spectrometry analysis showed that galectin-1 binds several membrane-associated proteins including HSP90. Finally, functional assays showed that binding of galectin- 8 could significantly enhance the acrosome reaction within human sperms. It was the first construction of a human lectin microarray.

\begin{tabular}{|c|c|c|c|c|c|c|}
\hline \multirow[t]{2}{*}{$\begin{array}{l}\text { Studied } \\
\text { indicators }\end{array}$} & \multirow[t]{2}{*}{ Group } & \multirow{2}{*}{$\begin{array}{ll}\begin{array}{l}\text { Number } \\
\text { does }\end{array} & \text { AI } \\
\mathbf{n} & \\
\end{array}$} & \multirow{2}{*}{$\begin{array}{l}\text { Number of live- } \\
\text { born pups in } \\
\text { litter } \\
\mathrm{X} \pm \text { SD }\end{array}$} & \multirow{2}{*}{$\begin{array}{l}\begin{array}{l}\text { Number } \\
\text { dead } \begin{array}{r}\text { of } \\
\text { born }\end{array} \\
\text { pups in litter }\end{array} \\
X\end{array}$} & $\begin{array}{l}\text { Weight of } \\
\text { live-born } \\
\text { pups }\end{array}$ & \multirow[t]{2}{*}{$\begin{array}{l}\text { Conception ratio } \\
(\%)\end{array}$} \\
\hline & & & & & $\mathrm{X} \pm \mathrm{SD}$ & \\
\hline \multirow{3}{*}{$\begin{array}{l}\text { Production breed } \\
P\end{array}$} & Experimental 1 & 100 & $10.19 \pm 3.17$ & 0.29 & $\begin{array}{l}60.12 \\
7.68\end{array}$ & 86.00 \\
\hline & Control 1 & 138 & $9,82 \pm 3.74$ & 0.24 & $\begin{array}{l}59.57 \\
8.16 \\
\end{array}$ & 83.33 \\
\hline & Statistics differences & & $\mathrm{p}>0.05$ & $\mathrm{p}>0.05$ & $\mathrm{p}>0.05$ & $\chi^{2}=0.08^{(-)}$ \\
\hline \multirow{3}{*}{$\begin{array}{l}\text { Experimental } \\
\text { breed } \\
E\end{array}$} & Experimental 2 & 54 & $9.65 \pm 3.50$ & 0.28 & $\begin{array}{l}61.12 \\
6.19\end{array}$ & 72.22 \\
\hline & Control 2 & 37 & $8.70 \pm 4.22$ & 0.85 & $\begin{array}{l}62.05 \\
9.28\end{array}$ & 64.86 \\
\hline & Statistics differences & & $\mathrm{p} \leq 0.05$ & $\mathrm{p}>0.05$ & $\mathrm{p}>0.05$ & $\chi^{2}=0.75^{(-)}$ \\
\hline
\end{tabular}

Legend: (-) statistically non-significant, (+) statistically significant

\section{CONCLUSION}

Lectins are becoming very popular with a widespread use and application in biological science. This study provides more light on the complexity of interactions between spermatozoa and ovule after ID incubation with lectin HPA. Conception ratios obtained from 2 different breeds $(\mathrm{P}, \mathrm{E})$ showed minor improvement $(+2.67 \% \mathrm{P} ;+7.36 \% \mathrm{E})$ between the monitored groups of females, however without statistically significant differences. Number of liveborn pups in litter obtained from breeds $\mathrm{P}$ and $\mathrm{E}$ showed minor improvements (+ 0.37 pcs $\mathrm{P} ;+0.95$ pcs E) compared to the control groups. The weight of live pups was comparable among the monitored groups. Lectin HPA at the insemination dose is only suitable in the experimental field of rabbit breeding. Its price is too high for its use in rabbit production. Future research should be focused on looking for similar substances with similar effect.

Acknowledgements: This research was supported by VEGA 1/0511/15 grant and VEGA 1/0625/15.

\section{REFERENCES}

ANCHORNDOGERY, J.J., RUDOLPH, A.S., CARPENTER, J.F., CROWE J.H. 1987. Modes of interaction of cryoprotectants with membrane phospholipids during freezing. Cryobiology. 24(6), 559-560. https://doi.org/10.1016/0011 2240(87)90104-0

BALDUS, S.E., HANISCH, F.G. 2000. Biochemistry and pathologica importance of mucin-associated antigens in gastrointestinal neoplasia, Advances in Cancer Research, 79, 201-248. https://doi.org/10.1016/S0065230X(00)79007-5 BLONSKI, K., MILDELANGOSCH, K., BAMBERGER, A.M., OSTERHOLZ, T., UTLER, C., BERGER, J., LONING, T., SCHUMACHER, U. 2007. Ulex europaeus agglutinin-I binding as a potential prognostic marker in ovarian cancer, Anticancer Research, 27, 2785-2790.

BROOKS, S.A. 2000.The involvement of Helix pomatia lectin (HPA) binding Nacetylgalactosamine glycans in cancer progression, Histol Histopathol, 15, 143 158.

CASTELLINI, C., BATTAGLINI, M., LATTAIOLI, P. 1992. Effects of cryoprotectants and freezing on rabbit semen quality. The Journal of Applied Rabbit Research, 15, 431-438

CHAMPION, Z.J., VICKERS, M.H., GRAVANCE, C.G., BREIER, B.H., CASAY, P.J. 1997. Growth hormone or insulin-like growth factor - I extends of longevity equine spermatozoa in vitro. Theriogenology, 7, 1793-1800. http://dx.doi.org/10.1016/S0093-691X(02)00640-4

CROSS, N.L., OVERSTREET, J.W. 1987. Glycoconjugates of the human sperm surface: distribution and alterations that accompany capacitation in vitro. Gamete Research, 16(1), 23-35. https://doi.org/10.1002/mrd.1120160104

DESANTIS, S., VENTRIGLIA, G., ZIZZA, S., NICASSIO, M., VALENTINI, L., DI SUMMA, A., LACANDRA, G.M. 2010. Lectin-binding sites on ejaculated stallion sperm during breeding and non-breeding periods Theriogenology.

https://doi.org/10.1016/j.theriogenology.2009.12.001

DUURAČKA, M., HALENÁR, M., TVRDÁ, E. 2017. In vitro effect of selected biologically active coumpounds on rabbit spermatozoa motility behaviour. Journal of Microbiology, Biotechnology and Food Sciences, 6(6),1290-1294 https://doi.org/10.15414/jmbfs.2017.6.6.1290-1294
FIK, M., HANUSOVÁ, J., TOČKA, I. 2008a. Zhodnotenie vybraných reprodukčných parametrov u brojlerových králičíc po ovplyvnení inseminačnej dávky implementorom heparínom. II. Medzinárodné vedecké hydinárske dni. Zbornik abstraktov. 2008. Nitra. 59.

FIK, M., PARKÁNYI, V., ONDRUŠKA, L', TOČKA, I. 2008b. Zhodnotenie vybraných reprodukčných parametrov u samíc brojlerových králikov po ovplyvnení inseminačnej dávky implementorom heparínom. XXIV. konferencia Aktuálne smery v chove brojlerových králikov, Nitra, 6.

FIK, M., PARKÁNYI, V., ONDRUŠKA, L., TOČKA, I. 2008c. Zhodnotenie prídavku rôznych dávok heparínu ako implementora do inseminačnej dávky samíc brojlerových králikov. XXIV.konferencia Aktuálne smery vchove brojlerových králikov. Nitra, 3.

FIK, M. 2009. Možnosti ovplyvnenia kapacitácie spermii králika. Nitra: SPU. Dissertation work, 77-104.

FIK, M., PARKÁNYI, V., ONDRUŠKA, L', LUKÁČ, N., CHLEBO, R. 2011. Effect of GnRH (Lecirelinum) on Selected Quality Parameters of rabbit Ejaculate. Acta fytotechnica et zootechnica, 14(4), 108-112.

FIK, M., MALÍKOVÁ, L. 2013. The Impact of Heparin Implementer (GAG) in the Rabbit Insemination Dose. Journal of Microbiology, Biotechnology and Food Sciences , 3 (2) 188-190

FIK, M., PARKÁNYI, V., ONDRUŠKA, L'., MALÍKOVÁ, L. 2014. Evaluation of Reproductive Performence of Does after Treatment with Insemination Dose Implementer heparin. Journal of Microbiology, Biotechnology and Food Sciences, 4 (3), 217-219 https://doi.org/10.15414/jmbfs.2014-15.4.3.217-219

FIK, M. 2018. Posssibilities of lecirelinum (GnRH) use in rabbits insemination. Journal of Microbiology, Biotechnology and Food Sciences, 7 (5) 511-515 https://doi.org/10.15414/jmbfs.2018.7.5.467-471

GOGOL, P. 2016. Effect of goserelin and leuprolide added to the semen on reproductive performance in rabbits. Acta Veterinaria Hungarica, 64, 116-119 https://doi.org/10.1556/004.2016.012

HANDERSON, T., CAMP, R., HARIGOPAL, M., RIMM, D., PAWELEK, J. 2005. $\beta 1,6$-branched oligosaccharides are increased in lymph node metastases and predict poor outcome in breast carcinoma. Clinical Cancer Research, 11, 2969-2973. https://doi.org/10.1158/1078-0432.CCR-04-2211

HASHIM, F., TVRDÁ, E., GREIFOVÁ, H., LUKÁČ, N. 2017. Effect of vitamins on the Quality of insemination dose of bulls. Journal of Microbiology, Biotechnology and Food Sciences, 7(3), 242-247. https://doi.org/10.15414/jmbfs.2017/18.7.3.242-247

HERMO, L., WINIKOFF, R., KAN, F.W. 1992. Quantitative changes of Ricinus communis agglutinin I and Helix pomatia lectin binding sites in the acrosome of rat spermatozoa during epididymal transit. Histochemistry. 98(2), 93-103.

JANUSKAUSKAS, A., GIL, J., SÖDERQUIST, L., RODRIGUEZ-MARTINEZ H. 2000. Relationship between Sperm Response to Glycosaminoglycans in vitro and Non-return Rates of Swedish Dairy AI Bulls. Reproduction in Domestic Animals. 35(5), 207-212 http://dx.doi.org/10.1046/j.1439-0531.2000.00212.x LAPOINTE, S., AHMAD, I., BUHR, M.M., LANBERT, R.D., SIRARD, M.A. 1996. Modulation of post-thaw motility, survival, calcium uptake, and fertility of bovine sperm by female genital products. Journal of Dairy Science, 79, 2155 2162. https://doi.org/10.3168/jds.s0022-0302(96)76591-8

MARTIN, M. 1993. Congelación de semen de conejo. Efecto de algunos agentes crioprotectores sobre la viabilidad espermotica. ITEA 12 (suppl) 486-488 IN Vicente, J.S. \& Viudes-de-Castro, M.P. 1996. A sucrose-DMSO extender for freezing rabbit semen. Reproduction Nutrition Development. 36, 485-492. https://doi.org/10.1051/rnd:19960504 
MATEJAŠÁKOVÁ, E., PIVKO, J., RIHA. L., MAKAREVICH, A.V., SIROTKIN, A.V. 2005. Vplyv vybraných rastových faktorov na aktivitu semena baranov. Košice. 20-28.

MITCHELL, B.S., SCHUMACHER, U. 1999. The use of the lectin Helix pomatia agglutinin (HPA) as a prognostic indicator and as a tool in cancer research. Histol Histopathol. 14(1), 217-26.

ONDRUSKKA, L', PARKANYI, V., RAFAY, J., CHLEBEC, I. 2008. Effect of LHRH analogue included in seminal dose on kindling rate a prolifacacy of rabbits artificially inseminated. $9^{\text {th }}$ Word Rabbit Congress. 9, 423-425.

PARKÁNYI, V., ONDRUŠKA, L., RAFAY, J. 2005. Improving of fertilization ability of rabbit spermatozoa: preliminary results. Giornate di Coniglicoltura ASIC, $14,87$.

PARRISH, J.J., VRENDENBURGH, W.L., LAVIN, C.A. 1993. Increases in bovine sperm intracellular calcium (Cai) and $\mathrm{pH}(\mathrm{pHi})$ during capacitation Biology of Reproduction. 48, 106.

RIHA, L., APOLEN, D., PIVKO, J., GRAFENAU, P., KUBOVIČOVÁ, E. 2006. Vplyv implementorov na oplodnenost' oviec v mimosezónnom období. Slovak Journal of Animal Science, 39(4), 180 - 182

SAHA, R.S., TUHIN, S.H.M., JAHAN, N., ROY, A., ROY, P. (2014) Antibacterial and antioxidant activities of a food lectin isolated from the seeds of lablab purpureous. American Journal of Ethnomedicine, 1 (1), 008-017.

SANCHEZ, J.F., LESCAR, J., CHAZALET, V., AUDFRAY, A., GAGNON, J., ALVAREZ, R., BRETON, C., IIMBERTY, A., MITCHELL, E.P. 2006. Structure of Helix Pomatia agglutinin with no ligands. Journal of Biological Chemistry, 281(29). https://doi.org/10.2210/pdb2ce6/pdb

SARLÓS, P., MOLNAR, A., KOKAI, M., GABOR, G., RATKY, J. 2002. Comparative evaluation of the effect of antioxidants in the conservation of ram semen. Acta Veterinaria Hungarica, 50 (2), 235 - 245. https://doi.org/10.1556/avet.50.2002.2.13

SLANINA, T., KOVÁČOVÁ, R., LUKÁČ, N., MASSÁNYI, P. 2016. Impact of tilmicosin on the rabbit spermatozoa motility and viability. Journal of Microbiology, Biotechnology and Food Sciences, 5(1), 53-56. https://doi.org/10.15414/jmbfs.2016.5.special1.53-56

SLANINA, T., MIŠKEJ, M., TIRPÁK, F., BŁASZCYK, M., FORMICKI, G., MASSANYI, P. 2018. Caffeine strongly improves motility parameters of turkey spermatozoa with no effect on cell viability. Acta Veterinaria Hungarica, 66(1), 137-150. https://doi.org/10.1556/004.2018.013

TATHAN, B.G., FEEHANT, T., PASHEN, R. 2003. Buffalo and cattle hybrid embryo development is decreased by caffeine treatment during in vitro fertilization. Theriogenology, 59(3-4), 709-717. https://doi.org/10.1016/s0093691x(02)01124-x

TIRPÁK, F., SLANINA, T., KOVÁČIK, A., ONDRUŠKA, L, MASSÁNYI, P. Jr., HALO, M. Jr., MASSÁNYI, P. 2017. Low taurine concentrations possitively affect rabbit spermatozoa properties in later time intervals. Journal of Microbiology, Biotechnology and Food Sciences, 7(2), 128-131 https://doi.org/10.15414/jmbfs.2017.7.2.128-131

TVRDÁ, E., MICHALKO, J., MATUŠÍKOVÁ, I., LUKÁČ, N. 2015a. The Drosera extract as an alternative in vitro supplement to animal semen: effects on bovine spermatozoa activity and oxidative balance. Scientific Papers: Anima Science and Biotechnologies, 48(1), 68-75. TVRDÁ, E., KOVÁČIK, A., TUŠIMOVÁ, E., LUKÁČ, N., LUKÁČOVÁ, J., MASSÁNYI, P. 2015b. Antioxidant efficiency of resveratrol on oxidative stress-induced damage in bovine spermatozoa. Journal of Microbiology, Biotechnology and Food Sciences, 5(1), 64-67 https://doi.org/10.15414/jmbfs.2015.5.1.64-67

TVRDÁ, E MICHALKO, J., MATUŠíKOVÁ, I, LUKÁC̆, N 2016. In Vitro Effects of the Chlamydomonas reinhardtii Extract on Bovine Spermatozoa Journal of Microbiology, Biotechnology and Food Sciences, 6(3), 972 - 975. https://doi.org/10.15414/jmbfs.2016/17.6.3.972-975

VAŠÍČEK, J. 2009. Vplyv intravaginálnej aplikácie glykózaminoglykánu v inseminačnej dávke králika na interakciu spermia - vajíčko. Slovenská pol'nohospodárska univerzita v Nitre. Diploma thesis. 2009, s. 58 - 69 .

VICKERS, M.H., CASEY, P.J., CHAMPION, Z.J. , GRAVANCE,C.G., BREIER, B.H. 1999. IgF - I treatment increases mobility and implroves morphology of immature spermatozoa in the GH- deficient dwarf (dw/dew) rat. Growth hormone \& IGF research, 9, 236-240. https://doi.org/10.1054/ghir.1999.0114

VICENTE, J.S., LAVARA, R., MARCO-JIMÉNEZ, F., VIUDES-DE-CASTRO, M.P. 2011. Detrimental effect on availability of buserelin acetate administered in seminal doses in rabbits. Theriogenology, 76, 1120-1125. http://dx.doi.org/10.1016/j.theriogenology.2011.05.020

VICENTE, J.S., VIUDES-DE-CASTRO, M.P. 1996. A sucrose-DMSO extender for freezing rabbit semen. Reproduction Nutrition Development. 36, 485-492. https://doi.org/10.1051/rnd:19960504

TAKANO, Y., TERANISHI, Y., TERASHIMA, S., MOTOKI, R. KAWAGUCHI, T. 2000. Lymph node metastasis-related carbohydrate epitopes of gastric cancer with submucosal invasion. Surgery Today, 2000, 30,1073-1082. https://doi.org/10.1007/s005950070004

YANGYANG, S., LI, C., YIHUA, G., AIJIE, X., BIN, W., SHUMIN, Z. SHUJUAN, G., YIN, L., HUIJUAN, S,. GUANGYU, W., SHENG-CE, T.2016. A Human Lectin Microarray for Sperm Surface Glycosylation Analysis. The
American Society for Biochemistry and Molecular Biology.15(9),28392851.https://doi.org/10.1074/mcp.m116.059311

ZIBRÍN, M., TOMAJKOVÁ, E., ČERNAJOVÁ, M. 2005. Bunková membrána spermii - teória a praktické dôsledky. In: MATEJAŠ́́KOVÁ, E., PIVKO, J., MAKAREVICH, A.V., KUBOVIČOVÁ, E., SIROTKIN, A.V., RIHA, L. 2005. Vplyv vybraných implementorov na ultraštrukturálnu kategorizáciu spermil barana. On-line: $\leq$ http://kfzfbp.uniag.sk/konferencie/csfz/proceeding\% $\% 2$ 0book/zbornik2005.pdf> 